\title{
INCUBATIONAL QUALITY OF EGGS AND EMBRIONAL DEVELOPMENT OF CHICKENS DEPENDING ON THE STORAGE TIMES
}

\section{Goncharyk Olga}

National University of Life and Environmental Sciences of Ukraine, Kyiv, Ukraine

\section{ІНКУБАЦІЙНІ ЯКОСТІ ЯЄЦЬ ТА ЕМБРІОНАЛЬНИЙ РОЗВИТОК КУРЧАТ ЗАЛЕЖНО ВІД ТЕРМІНІВ ЗБЕРІГАННЯ}

\section{Гончарик Ольга}

Received 26. 6. 2017

Revised 28. 6. 2017

Published 27. 11. 2017

\begin{abstract}
The article presents the results of evaluation of the effects of storage periods (1, 5, 8, 11 days) on incubation eggs of chickens of modern specialized egg crosses on their incubation qualities and embryonic development of chickens. The significant influence of the storage period and age of the parent herd on the investigated parameters is established. On the basis of biological control, it was found that the highest number of eggs with a "blood ring" ( 6.6 and $8.8 \%$ ) was observed during the incubation of chicken eggs of "white" and "brown" cross, respectively, at the age of 80 weeks for lengthening the storage period until 8 weeks, as well as for eggs, obtained from birds of both crosses for 11-day storage (2.9-5.1\%). The largest number of "dysfunctions" compared to other experimental groups of eggs was found for chicken eggs of the Hayesz brown class at the age of 28 and $60-80$ weeks, for the Hayes white cross - at the age of 28-34 and 80 weeks of all storage periods. For the studied crosses, a sharp increase in the yield of weak chicks (up to $1.5-2.2 \%$ ) was found during the incubation of eggs from poultry 42-60 weeks of age for storage of 8 days and more, as well as 80 -week old birds. Thus, qualitative indices of the incubation eggs of chickens of modern specialized crosses are largely determined both by the age of the bird of the parent flock and the duration of the pre-incubation storage of eggs. At acceptable fertility rates of 80-weekold eggs, the level of withdrawability is significantly lower by increasing the number of dead embryos and weak chickens. Extension of the shelf life of incubation eggs leads to an increase in the number of frozen embryos and "dysfunctions". In order to increase the profitability of the technological process in the incubator, it is necessary to carry out a comprehensive analysis of the expediency of incubating poultry eggs for a different storage period.
\end{abstract}

Keywords: incubation; egg incubation; shelf life; embryonal development

\section{Вступ}

Отримання максимальної кількості молодняку високої якості - основне завдання племінних птахівничих господарств і, зокрема, інкубаторів. Якість молодняку визначається ще у період ембріонального розвитку і залежить від генетичних факторів, умов утримання та годівлі батьківського поголів'я, біологічної повноцінності яєць, умов їх зберігання після знесення, технології інкубації та умов, в яких він знаходиться після виводу до передачі на вирощування

*Corresponding author: Olga Goncharyk, National University of Life and Environmental Sciences of Ukraine, Kyiv, Ukraine, $\bowtie$ honcharykolga@gmail.com 
(Ткаченко та ін., 2009; Гончарик та Пономаренко, 2015). Часто за об'єктивних причин внаслідок варіабельності замовлень і обсягів, сезонних коливань попиту на добовий молодняк практикують подовження термінів зберігання яєць перед інкубацією.

Пролонговане зберігання інкубаційних яєць загалом має негативний вплив на результати інкубації - зі збільшенням термінів зберігання внутрішня якість яєць знижується, що виражається як у зниженні якості білка, так і цілісності вітеллінової оболонки; спостерігається також і відмирання клітин ембріону. Крім того, спостерігається подовження строків інкубації яєць, тобто збільшується «вікно виводимості», що впливає на якісні показники отримуваних курчат (Бурдашкіна, 2012). Для зниження негативного впливу тривалого зберігання інкубаційних яєць на їх якісні показники запропоновано певні технологічні прийоми, які використовуються у практичній роботі в інкубаторіях (Дядичкіна, 2008; Бурдашкіна, 2012).

Нині у птахівничих господарствах терміни використання птиці батьківського стада збільшуються, що $\epsilon$ економічно вигідним, при цьому накопичення яєць для формування партії для інкубації $є$ загальноприйнятим явищем. За таких умов вивчення впливу тривалості зберігання інкубаційних яєць птиці різного віку на їх якісні показники є актуальним. Тому метою нашої роботи було визначити вплив термінів зберігання інкубаційних яєць курей спеціалізованих яєчних кросів впродовж всього періоду використання на їх якісні показники.

\section{Матеріали та методи}

Дослідження проведені в умовах племінного птахівничого підприємства з розведення курей яєчних кросів «Хайсекс білий» і «Хайсекс коричневий». Для дослідження відбирали яйця, отримані від курей у віці 28, 34, 42, 60, 80 тижнів. Закладання яєць на інкубацію здійснювали на 1-й, 5-й, 8-й, 11-й день після знесення. Умови зберігання яєць перед інкубацією і технологія інкубації яєць у господарстві відповідали існуючим вимогам. Впродовж інкубації проводили біологічний контроль, після виводу - оцінку інкубаційних якостей яєць і молодняку птиці.

\section{Результати та їх обговорення}

За результатами проведених досліджень (табл. 1) відзначимо загалом високий рівень заплідненості яєць. Значення цього показника коливалися в межах 87,5 - 97,8 \% і 80,14 98,57 \% для курей «коричневого» і «білого» кросу відповідно. Щодо курей кросу «Хайсекс коричневий» - найвищий рівень цього показника спостерігали у птиці 34 - 42-тижневого віку, надалі - поступове зниження, але і у віці 80 тижнів цей показник становив 90,44 - 97,8, що $\epsilon$ доволі високого рівня. Для курей кросу «Хайсекс білий» спостерігали подібну тенденцію, але при цьому зниження рівня показника наприкінці продуктивного використання птиці $\epsilon$ значно більшим - до 80,14 - 88,97 \%.

Аналіз показника виводимості яєць $€$ основним при визначенні впливу термінів зберігання інкубаційних яєць на їх якість. Загалом рівень виводимості яєць курей «коричневого» кросу варіює в межах 75,4 - 90,5 \%, «білого» кросу» - 74,3 - 93,5 \%, при цьому чітко простежується тенденція до зниження виводимості залежно від терміну зберігання. Виводимість яєць знижується зі збільшенням терміну зберігання - на 4,5 - 8,2 \% для «коричневого» кросу, на 2,7 - 5,4 \% - для «білого» кросу. Так, виводимість яєць курей кросу «Хайсекс коричневий» за мінімального терміну зберігання становить 80,6 - 90,5 \%, за зберігання впродовж 8 діб показник виводимості знижується і становить 77,0 - 87,0 \%. Для яєць курей кросу «Хайсекс білий» ці значення становили 80,0 - 93,5 та 74,3 - 89,1\%. Відзначимо, що найменше зниження виводимості яєць спостерігали при інкубації яєць, отриманих від курей віком $34-60$ тижнів для обох досліджуваних кросів. 
Таблиця 1 Результати інкубації яєць за різних термінів їх зберігання

Table 1

\begin{tabular}{|c|c|c|c|c|c|c|c|c|c|c|c|}
\hline \multirow[t]{2}{*}{ Показник } & \multirow{2}{*}{$\begin{array}{c}\text { Термін } \\
\text { зберігання } \\
\text { яєць, діб }\end{array}$} & \multicolumn{5}{|c|}{$\begin{array}{c}\text { Крос «Хайсекс коричневий» } \\
\text { вік птиці, тижні }\end{array}$} & \multicolumn{5}{|c|}{$\begin{array}{l}\text { Крос «Хайсекс білий» } \\
\text { вік птиці, тижні }\end{array}$} \\
\hline & & 28 & 34 & 42 & 60 & 80 & 28 & 34 & 42 & 60 & 80 \\
\hline \multirow{4}{*}{$\begin{array}{l}\text { Заплідненість, } \\
\%\end{array}$} & 1 & 97,14 & 97,86 & 95,72 & 92,14 & 97,80 & 96,0 & 97,24 & 98,57 & 94,85 & 88,24 \\
\hline & 5 & 94,50 & 96,43 & 90,72 & 87,50 & 91,18 & 96,0 & 97,24 & 98,53 & 95,59 & 88,97 \\
\hline & 8 & 89,66 & 91,90 & 96,31 & 89,71 & 90,44 & 96,71 & 96,43 & 98,57 & 91,91 & 80,14 \\
\hline & 11 & - & 97,14 & 95,72 & 86,76 & 91,91 & 97,06 & 95,59 & - & - & - \\
\hline \multirow{4}{*}{$\begin{array}{l}\text { Виводимість, } \\
\%\end{array}$} & 1 & 85,3 & 90,5 & 88,8 & 80,6 & 85,0 & 81,9 & 87,2 & 93,5 & 89,1 & 80,0 \\
\hline & 5 & 83,2 & 87,4 & 86,6 & 78,2 & 82,3 & 81,9 & 85,8 & 90,3 & 86,9 & 76,9 \\
\hline & 8 & 79,2 & 86,4 & 87,0 & 77,0 & 77,2 & 77,2 & 85,2 & 89,1 & 86,4 & 74,3 \\
\hline & 11 & - & 86,8 & 84,3 & 75,4 & 76,8 & 85,6 & 87,7 & - & - & - \\
\hline \multirow{4}{*}{ Вивід, \% } & 1 & 82,9 & 88,6 & 85,0 & 74,3 & 83,1 & 78,7 & 84,8 & 92,1 & 84,6 & 70,6 \\
\hline & 5 & 78,6 & 84,3 & 78,6 & 68,4 & 75,0 & 78,7 & 83,4 & 89,0 & 83,1 & 68,4 \\
\hline & 8 & 71,0 & 79,4 & 83,8 & 69,1 & 69,9 & 74,7 & 82,1 & 87,9 & 79,4 & 59,6 \\
\hline & 11 & - & 84,3 & 80,7 & 65,4 & 70,6 & 83,1 & 83,8 & - & - & - \\
\hline \multirow{4}{*}{$\begin{array}{l}\text { «Кров'яне } \\
\text { кільце», \% }\end{array}$} & 1 & 2,1 & 2,1 & 1,4 & 3,6 & 2,2 & 2,7 & 1,4 & 0,7 & 1,5 & 1,5 \\
\hline & 5 & 2,1 & 1,4 & 2,9 & 3,7 & 5,1 & 2,7 & 2,8 & 2,9 & 2,9 & 2,9 \\
\hline & 8 & 2,8 & 2,2 & 2,9 & 3,7 & 8,8 & 3,3 & 2,9 & 3,6 & 2,9 & 6,6 \\
\hline & 11 & - & 5,0 & 3,6 & 3,7 & 2,9 & 5,1 & 3,7 & - & - & - \\
\hline \multirow{4}{*}{$\begin{array}{l}\text { «Задохлики», } \\
\%\end{array}$} & 1 & 9,3 & 5,7 & 8,6 & 10,7 & 8,8 & 8,0 & 7,6 & 4,3 & 8,1 & 14,0 \\
\hline & 5 & 11,7 & 8,6 & 7,1 & 15,4 & 6,6 & 10,0 & 8,3 & 4,4 & 6,6 & 11,0 \\
\hline & 8 & 13,8 & 7,4 & 6,6 & 15,4 & 9,6 & 12,7 & 9,3 & 4,3 & 5,1 & 11,8 \\
\hline & 11 & - & 5,7 & 7,1 & 15,4 & 15,4 & 6,6 & 5,1 & - & - & - \\
\hline \multirow{4}{*}{ Усушка, \% } & 1 & 4,0 & 4,2 & 4,5 & 5,6 & 5,3 & 4,2 & 3,2 & 3,6 & 3,4 & 3,7 \\
\hline & 5 & 4,4 & 5,1 & 4,4 & 5,1 & 6,4 & 4,4 & 3,6 & 5,1 & 4,1 & 4,8 \\
\hline & 8 & 4,5 & 4,1 & 5,0 & 5,1 & 5,5 & 4,5 & 3,8 & 2,8 & 4,2 & 4,5 \\
\hline & 11 & - & 4,9 & 3,4 & 7,4 & 5,9 & 4,5 & 3,4 & - & - & - \\
\hline \multirow{4}{*}{$\begin{array}{l}\text { Слабі курчата, } \\
\text { каліки, \% }\end{array}$} & 1 & 0,7 & 0,0 & 0,0 & 2,1 & 1,5 & 2,7 & 1,4 & 0,7 & 0,7 & 2,2 \\
\hline & 5 & 0,7 & 0,7 & 0,7 & 0,0 & 2,2 & 2,0 & 1,4 & 0,7 & 1,5 & 2,2 \\
\hline & 8 & 0,7 & 0,7 & 1,5 & 0,7 & 1,5 & 2,7 & 0,7 & 2,1 & 2,2 & 2,2 \\
\hline & 11 & - & 0,0 & 2,1 & 0,7 & 1,5 & 1,5 & 1,5 & - & - & - \\
\hline
\end{tabular}


Враховуючи вищезазначене, зрозумілим $\epsilon$ нижчий рівень цього показника за тривалого зберігання яєць, особливо щодо яєць, які отримані від птиці у молодому і старшому віці у 28 і 80 тижнів, що свідчить про нижчий рівень їх якості.

На основі проведеного біологічного контролю встановлено, що найвища кількість яєць 3 «кров'яним кільцем» (6,6 та 8,8 \%) відзначена при інкубації яєць курей «білого» і «коричневого» кросу відповідно віком 80 тижнів за подовження термінів зберігання до 8 тижнів, а також для яєць, отриманих від птиці обох кросів за 11-добового їх зберігання (2,9 - 5,1%).

Найбільша кількість «задохликів» порівняно з іншими дослідними групами яєць встановлена для груп яєць курей кросу «Хайсекс коричневий» у віці 28 та 60 - 80 тижнів, для кросу «Хайсекс білий» - у віці 28 - 34 та 80 тижнів всіх термінів зберігання.

Для досліджуваних кросів виявилось характерним різке збільшення виходу слабких курчат (до 1,5 - 2,2 \%) при інкубації яєць, отриманих від птиці 42 - 60-тижневого віку за зберігання 8 діб і вище, а також птиці 80-тижневого віку.

\section{Висновки}

Якісні показники інкубаційних яєць курей сучасних спеціалізованих кросів значною мірою визначаються як віком птиці батьківського стада, так і тривалістю передінкубаційного зберігання яєць. За прийнятних показників заплідненості яєць птиці 80-тижневого віку рівень виводимості $\epsilon$ значно нижчим за рахунок підвищення кількості загиблих ембріонів та слабких курчат. Подовження термінів зберігання інкубаційних яєць призводить до збільшення кількості завмерлих ембріонів та «задохликів». Для підвищення показників рентабельності технологічного процесу в інкубаторії необхідним $\epsilon$ проведення комплексного аналізу доцільності інкубації яєць птиці за різного терміну зберігання яєць.

\section{Література}

Бурдашкіна, В. 2012. Возраст родительского стада и инкубационные качества яйца [Електронний ресурс]. Режим доступу: http://webpticeprom.ru/ru/articles-pedigree.html?pagelD=1328276678

Гончарик, О.А., Пономаренко, Н.П. 2015. Оцінювання якості інкубаційних яєць курей за різних термінів їх зберігання. Сучасне птахівничтво, №10 (155), с. 19-20.

Дядичкіна, Л. 2008. Возраст кур и сроки хранения яйца. Животноводство России, № 5, с. 21.

Ткаченко, С.М., Шоміна, Н.В., Тагіров, М.Т., Терещенко, О.В. 2009. Вплив довготривалого зберігання яєць на якість добового молодняку. Птахівництво: міжвідомчий тематичний науковий збірник. Харків, вип. 64, с. 174-182. 